JURNAL PENDIDIKAN USIA DINI

DOI: https://doi.org/10.21009/JPUD.112

DOI: https://doi.org/10.21009/JPUD.112.14

\title{
PENGARUH GAYA KEPEMIMPINAN KEPALA SEKOLAH DAN IKLIM ORGANISASI DENGAN KINERJA GURU PENDIDIKAN ANAK USIA DINI
}

\author{
WINDA WIRASTI AGUSWARA ${ }^{1}$-REZA RACHMADTULLAH ${ }^{2}$ \\ Universitas Negeri Jakarta,Jakarta.Indonesia ${ }^{1}$ \\ Email: winda.guswara12@gmail.com \\ Universitas PGRI Adi Buana,Surabaya.Indonesia ${ }^{2}$ \\ Email: rezarachmadtullaheza@gmail.com
}

\begin{abstract}
This study aims to determine the influence of principal leadership style and organizational climate on the performance of early childhood education teachers in Mempawah District, West Kalimantan Province. The method to be used in this research is survey method using path analysis technique. The population in this study is the teacher of Early Childhood Education in Mempawah District, West Kalimantan Province, as many as 60 respondents. The sampling technique used is a simple random sampling technique. The results of this study indicate a significant influence between the leadership style of leadership and organizational climate on the performance of teachers of Early Childhood Education in Kabupaten Mempawah West Kalimantan Province
\end{abstract}

Keywords: Principal Leadership Style, Organizational Climate. Teacher Performance

\begin{abstract}
Abstrak: Tujuan penelitian mencari tau tentang pengaruh gaya kepemimpinan kepala sekolah dan iklim organisasi dengan kinerja guru pendidikan anak usia dini di Kabupaten Mempawah Provinsi Kalimantan Barat. Metode yang akan digunakan pada penelitian ini adalah metode survey dengan menggunakan teknik analisis Jalur (path analysis). Sampel penelitian ini adalah guru Pendidikan Anak Usia Dini di Kabupaten Mempawah Provinsi Kalimantan barat, sebanyak 60 responden. Teknik pengambilan sampel yang digunakan teknik simple random sampling. hasil dari penelitian ini menunjukan adanya signifikan antara pengaruh gaya kepemimpinan kepala sekolah dan iklim organisasi dengan kinerja guru Pendidikan Anak Usia Dini di Kabupaten Mempawah Provinsi Kalimantan Barat
\end{abstract}

Kata kunci: Gaya Kepemimpinan Kepala Sekolah, Iklim Organisasi. Kinerja Guru

\section{Pendahuluan}

Sebuah organisasi harus memiliki pemimpin (top manager) yang dapat menjalankan kegiatan yang berkaitan dengan ruang lingkup disebuah organisasi. Kepemimpinan merupakan 
kemampuan memanajemen dan beberapa hal, yaitu kelembagaan

memperngaruhi suatu kelompok kearah pencapaian suatu tujuan di organisasi tersebut.

Peran pemimpinan dapat diartikan sebagai upaya yang memiliki pengaruh bukan sifat paksaan untuk memotivasi anggota organisasi agar mencapai tujuan yang telah ditentukan..hal ini juga terjadi dalam pengelolana pendidikan anak usia dini sehingga peran pendidiakan anak usia dini dapat tercapai sesuai Permendikdas No 58 tahun 2009 yaitu Pendidikan anak usia dini merupakan bentuk penyelenggaraan pendidikan yang menitik beratkan pada peletakan dasar ke arah pertumbuhan dan lima perkembangan, yaitu: perkembangan moral dan agama, perkembangan fisik (koordinasi motorik halus dan kasar), kecerdasan/kognitif (daya pikir, daya cipta), sosio emosional (sikap dan emosi) bahasa dan komunikasi, sesuai dengan keunikan dan tahap-tahap perkembangan sesuai kelompok usia yang dilalui oleh anak usia dini.

Strategi dalam mengelola PAUD menjadi baik, maka harus memahami pendidikan, kepemimpinan kepalas sekolah dan kinerja guru dalam melaksanakan metode pengajaran, dan kurikulum. Untuk mencapai strategi mengelola PAUD tersebut kualitas kinerja guru tidaklah mudah. Dalam Undang-Undang RI No.20 tahun 2003 pasal 39 ayat 1, menjelaskan bahwa tugas kependidikan bertugas melaksanakan administrasi pengelolaan, pengembangan, pengawasan, dan pelayanan teknis untuk menunjang proses pendidikan pada satuan pendidikan.

Pengembangan kompetensi guru PAUD tidak dapat terlepaskan dari sebuah kondisi atau suasana lingkungan di sebuah organisasi. Suasana organisasi yang nyaman akan sangat mendukung seorang guru untuk dapat mengembangkan kompetensinya. Iklim disebuah organisasi merupakan wujud dari karakteristik lingkungan kerja yang dirasakan guru sebagai bagian dari anggota organisasi yang memiliki peran yangpenting bagi meningkatkan kesuksesan institusi. Hal ini disebabkan sebuah iklim organisasi erat dengan 
Pengaruh Gaya Kepemimpinan............. Winda \& Reza

proses menciptakan suasana dan kerja yang kondusif nyaman dan dapat mengembangakan kopetensi seorang guru. Iklim organisasi kerja yang nyaman dan kondusif diharapkan dapat membantu guru PAUD untuk mencapai tujuan lembaga pendidikan dimana pada akhirnya akan meningkatkan kualitas organisasi tersebut.

Dinamika terjadi harus mendapat memberi perhatian dalam mengembangkan berbagai kompetensi guru PAUD, peran sorang kepala sekolah PAUD sebagai pemimpin yang dapat memberikan motivasi dan bimbingan untuk meningkatkan kinerja guru PAUD yang disesuaikan bagaimana kepala sekolah PAUD memeperlakukan pendekatan dalam kepemimpinannya.

\section{KAJIAN TEORITIK}

Rivai dan Mulyadi (2009:170) mengemukakan bahwa iklim organisasi serangkaian sifat lingkungan kerja ". dimana hubungan yang ada bersumber dari hubungan antara guru dengan guru lainnya, atau hubungan guru dengan kepala sekolah atau sebaliknya antara kepala sekolah dengan guru. Pola hubungan antara staf tenaga administrasi/tata usaha dengan kepala sekolah dalam membentuk suatu jenis kepemimpinan (leadership style) yang diterapkan oleh seorang pemimpin atau kepala sekolah dalam melaksanakan fungsi kepemimpinannya.

Dengan demikian dapat diambol kesimpulan bahwa kinerja guru PAUD pun meningkat. Salah satu dinamika yang harus mendapat perhatian dalam mengembangkan berbagai kompetensi guru peran sorang kepala sekolah sebagai pemeimpin yangmemberikan motivasi dan bimbingan untuk meningkatkan kinerja guru disesuaikan bagaimana cara kepala sekolah tersebut melakukan pendekatan-pendekatan dalam kepemimpinannya. Menurut Thoha (2009:49) gaya kepemimpinan merupakan norma perilaku digunakan oleh seseorang pada saat orang tersebut mencoba mempengaruhi perilaku orang lain. Hal ini dapat dilijat dari seseorang yang mempengaruhi perilaku orang lain maka ia melibatkan seseorang kedalam aktivitas kepemimpinanmya. Dalam hal ini usaha mempengaruhi perilaku 
JURNAL PENDIDIKAN USIA DINI

Volume 11 Edisi 2, November 2017

dengan orang yang perilakunya akandipengaruhi menjadi amat penting kedudukannya.

Hersey and Kenneth (1982:152) mengemukakan

"situational leadership style based on the level of maturity of subordinates, including: telling, selling, participating delegating. The principal as the supreme leader in the school is very influential and determine the progress of the school should have the ability of administration, have a high commitment, and flexible in carrying out its duties".

Pendapat di atas dapat di pahami bahwa gaya kepemimpinan kepala sekolah PAUD harus dapat mengupayakan adanya peningkatan kinerja guru melalui program pembinaan kemampuan tenaga kependidikan di PAUD. Selanjutnya komunikasi seorang kepala sekolah PAUD harus dapat menyampaikan pesan menggunakan simbol-simbol atau tanda-tanda, dan isyarat-isyarat kontekstual dalam usahanya mengekspresikan maksudnya dan tujuan dengan mengirimkan informasi secara tepat sehingga pengertian yang sama dapat dibangun oleh orang lain yang menerimapesan tersebut (Hoy \& Miskel, 2013, p.390)

Menurut Mulyasa (2012:5) "kesuksesan pendidikan dan pembelajaran di sekolah dipengaruhi oleh kemampuan kepala sekolah dalam mengelola setiap komponen sekolah (who is behind the school )". Oleh karena itu kepala sekolah harus memiliki kepribadian dan kemampuan, keterampilan-keterampilan untuk memimpin lembaga PAUD.

Oleh sebab itu kepemimpinan yang baik adalah pemimpin yang dapat menciptakan kepemimpinaannya yang efektif. sehingga kepemimpinan efektif tersebut mampu mencapai tujuan sebuah organisasi mengerjakan tugasnya tepat pada waktunya. Sebab kepemimpinan yang efektif dapat melaksanakan dan memanfaatkan peran dan fungsi manajemen pengelolaan PAUD dengan baik termasuk melaksanakan perencanaan program kerja. Apabila kepemimpinan seorang pemimpinan kepala sekolah dapat 
Pengaruh Gaya Kepemimpinan............ Winda \& Reza

dijalankan dengan baik dan persoalan yang sering dihadapi adalah profesionalitas yang tinggi serta sulitnya menciptakan situasi iklim kerja didukung dengan iklim organisasi yang kondusif di sekolah dikarenakan sekolah yang kondusif maka dapat terwujud adanya peningkatan kinerja guru PAUD.

Dengan adanya hubungan yang harmonis dapat menciptakan iklim organisasi sekolah PAUD yang kondusif. Iklim kerja dalam konteks penelitian ini adalah budaya kerja di sekolah yang implikasinya dapat meningkatkan kualitas kerja di sekolah. Hal ini seperti dikemukakan oleh Sergiovanni (Suryaman, 2004: 67) "school climate has obvious implications for improving the quality of work life for those who in school". Iklim organisasi lebih banyak dipengaruhi oleh kepala sekolah, karena dialah yang meletakkan landasan dan struktur dimana terjadinya iteraksi sosial dalam organisasi sekolah.

Menurut Kusumawati (2000:45) "Pemimpin harus dapat menciptakan iklim budaya organisasi dimana seseorang merasa bebas namun bertanggung jawab", hal itu karena

adanya keaneka ragaman individu yang ada pada tiap - tiap sekolah.

Karakteristik gaya kepemimpinan yang memiliki orientasi pada tugas adalah melakukan komunikasi satu arah, menyusun rencana kerja, merancang tugas - tugas, menetapkan prosedur kerja dan menekankan pencapaian tujuan organisasi.

Sedangkan karakteristik perilaku gaya kepemimpinan yang berorientasi pada hubungan manusia adalah menjalin hubungan yang akrab dan menghargai anggota, bersikap hangat, serta menaruh kepercayaan kepada anggota.

Berdsarkan pendapat di katas orientasi kepemimpinan tersebut, selanjutnya (Rossow, 1990). Menjelaskan gaya kepemimpinan bisa diklasifikasi menjadi empat, yaitu: (1) Task oriented leadership, merupakan kepemimpinan yang berorientasi tinggi pada tugas, dan rendah anatara manusia. (2) Relationship oriented leadership, yakni cara kepemimpinan 
yang berorientasi anatara hubungan manusia, tetapi rendah pada tugas. (3) Integrated leadership, merupakan gaya kepemimpinan yang berorientasi tinggi pada tugas anatara manusia, dan (4) Impoverished leadership, yakni gaya kepemimpinan yang berorientasi rendah

Pada tugas dan hubungan manusia Kinerja guru yang diharapkan dapat mendongkrak kualitas dan relevansi pendidikan, dalam implementasinya di lapangan tergantung dari banyak faktor yang mempengaruhinya dan saling berkaitan, misalnya faktor kepemimpinan kepala sekolah dan iklim kerja.

Gaya kepemimpinan kepala sekolah sangat menentukanmutu, tanpa kepemimpinan yang baik proses peningkatan mutu tidak dapat dilakukan dan diwujudkan (Edwar Sallis, 2006:170).Thoha (2009:49) menegemukakan gaya kepemimpinan merupakan norma perilaku yang digunakan oleh seseorang pada saat orang tersebut mencoba mempengaruhi perilaku orang lain. Pada saat bagaimanapun jika seseorang berusaha untuk mempengaruhi perilaku orang lain maka ia telah melibatkan seseorang kedalam aktivitas kepemimpinan.

Gaya kepemimpinan kepala sekolah PAUD merupakan penentu berhasil atau mundurnya sekolah yang di pimpinnya. Agar fungsi kepemimpinan kepala sekolah PAUD berhasil memberdayakan segala sumber daya sekolah untuk mencapai tujuan sesuai dengan situasi, diperlukan kemampuan profesional, yaitu kepribadian, keahlian dasar, pengalaman dan keterampilan profesional, pelatihan dan pengetahuan profesional, serta kompetensi administrasi dan pengawasan.

Jauhari $(2005 ; 4)$ mengatakan, sebuah iklim organisasi sekolah merupakan persepsi para guru, karyawan dan personel sekolah tentang struktur kerja sekolah, gaya kepemimpinan, manajemen, supervisi, merupakan faktor lingkungan sosial penting lainnya yang tampak pada sikap, kepercayaan, nilai dan motivasi kerjanya.

Persepsi tersebut yang mempunyai dampak terhadap semangat 
Pengaruh Gaya Kepemimpinan............. Winda \& Reza

kerja atau moral kerja para guru dan karyawandan personil sekolah lainnya, yang pada akhirnya akan mempengaruhi kualitas proses belajar mengajar.

Menurut (Tjutju Yuniarsih dan Suwatno, 2008:166). Keutamaan (influence) sebagai gaya kepemimpinan kepala sekolah bukanlah semata-mata berbentuk instruksi, melainkan lebih merupakan motivasi yang dapat memberikan inspirasi terhadap para guru PAUD dan karyawan, sehingga inisiatif dan kreatifitasnya berkembang secara optimal untuk meningkatkan kinerjanya.

Berdasarkan uraian di atas maka tujuan dalam penelitian ini adalah
Pengaruh Gaya Kepemimpinan Kepala Sekolah Dan Iklim Organisasi Dengan Kinerja Guru Pendidikan Anak Usia Dini di Kabupaten Mempawah Provinsi Kalimantan Barat

\section{METODE PENELITIAN}

Penelitian ini menggunakan metode survey dengan teknik analisis jalur (path analysis). Populasi dalam penelitian ini adalah guru PAUD di Kabupaten Mempawah Provinsi Kalimantan barat, sebanyak 60 responden. Teknik pengambilan sampel menggunakan teknik simple random sampling. menggunakan instrumen adapun konstelasi penelitian sebagai berikut:

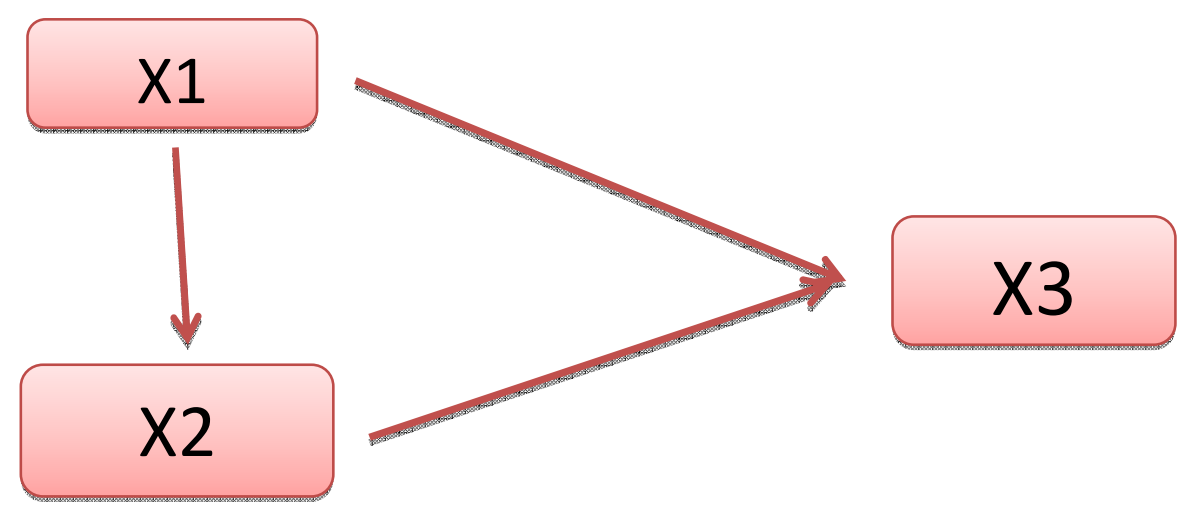

\section{Keterangan:}

Gambar 1 Kontelasi Penelitian

$\mathrm{X} 1$ : Gaya kepemimpinan kepala sekolah

X2 : Iklim Organisasi 
X3 : Kinerja guru PAUD (X3),

\section{HASIL DAN PEMBAHASAAN}

\section{Uji Homogenitas}

Uji Homogenitas dengan Uji

Bartlett dengan menggunakan nilai Chi-Kuadrat sebagai ukuran pengujian.Pasangan variabel kinerja guru $\left(\mathrm{X}_{3}\right)$ dengan gaya kepemimpinan kepala sekolah $\left(\mathrm{X}_{1}\right)$ diperoleh nilai $\mathrm{B}=$ 2,674nilai Chi-Kuadrat sebagai ukuran pengujian atau $x^{2}=6,158$. Dapat disimpulkan bahwa berdasarkan kaidah yang ditetapkan yaitu $\mathrm{X}^{2}$ hitung $<\mathrm{X}^{2}$ tabel $(6,158<79,08) \quad$ artinya dapat disimpulkan varians-variansnya homogen, sehingga memenuhi persyaratan analisis.

Pasangan variabel kinerja guru dengan Iklim organisasi diperoleh nilai
$\mathrm{B}=1,318$ sehingga nilai Chi-Kuadrat sebagai ukuran pengujian atau $\mathrm{x}^{2}=$ 3,036. Dapat disimpulkan berdasarkan kaidah yang ditetapkan yaitu $\mathrm{X}^{2}$ hitung $<$ $\mathrm{X}^{2}$ tabel $(3,036<79,08)$ artinya dapat disimpulkan varians-variansnya homogen, sehingga memenuhi persyaratan analisis.

Pasangan variabel gaya kepemimpinan kepala sekolah dengan Iklim organisasidiperoleh nilai $\mathrm{B}=$ 1,709nilai Chi-Kuadrat sebagai ukuran pengujian atau $\mathrm{X}^{2}=3,935$. berdasarkan kaidah yang ditetapkan yaitu $\mathrm{X}^{2}$ hitung $<$ $\mathrm{X}^{2}$ tabel $(3,935<79,08)$ artinya dapat disimpulkan varians-variansnya homogen, sehingga memenuhi persyaratan analisis.

\section{Pengujian Hipotesis}

Pengaruh Gaya Kepemimpinan Kepala Sekolah Terhadap Kinerja Guru

Tabel 1. ANOVA

\begin{tabular}{rlrrrrr}
\hline Model & & Sum of Squares & df & Mean Square & F & \multicolumn{1}{l}{ Sig. } \\
\hline 1 & Regression & 242.511 & 1 & 242.511 & 2.725 & $.104^{\mathrm{a}}$ \\
& Residual & 5162.472 & 58 & 89.008 & & \\
& Total & 5404.983 & 59 & & & \\
\hline
\end{tabular}


Tabel Anova menunjukan keberartian 7,08. Ternyata $F_{\text {hitung lebih kecil dari harga }}$ regresi melalui hasil yang diperoleh yaitu $\mathrm{F}_{\text {tabel }}\left(\mathrm{F}_{\text {hitung }}<\mathrm{F}_{\text {tabel }}\right)$, maka dapat $F_{\text {hitung }}$ sebesar 2,725 dan harga $F_{\text {tabel }}$ disimpulkan bahwa bentuk persamaan dengan dk pembilang 1 dan $\mathrm{dk}$ penyebut regresi $X_{1}$ atas $X_{3}$ adalah tidak linea (n-2=58) taraf signifikansi 0,05 diperoleh

Tabel 2. Coefficients

\begin{tabular}{|c|c|c|c|c|c|c|}
\hline & \multirow{3}{*}{ Model } & \multirow{2}{*}{\multicolumn{2}{|c|}{$\begin{array}{c}\text { Unstandardized } \\
\text { Coefficients }\end{array}$}} & \multirow{2}{*}{$\begin{array}{l}\text { Standardized } \\
\text { Coefficients }\end{array}$} & \multirow{3}{*}{$\mathrm{t}$} & \multirow{3}{*}{ Sig. } \\
\hline & & & & & & \\
\hline & & $\mathrm{B}$ & Std. Error & Beta & & \\
\hline \multirow[t]{2}{*}{1} & (Constant) & 68.454 & 7.409 & & 9.239 & .000 \\
\hline & Skor $X_{1}$ & .159 & .097 & .212 & 1.651 & .104 \\
\hline
\end{tabular}

Hasil dari uji Coefficients diatas, nilai konstanta $(\mathrm{a})=68,454$ dan beta $=$ 0,159. Dari tabel tersebut diperoleh persamaan linier perhitungannya adalah :X3 $=68,454+0,159 X 1$. Konstanta (a) 68,454 menyatakan bahwa jika tidak ada gaya kepemimpinan kepala sekolah PAUD, selanjutnya nilai kinerja guru diperoleh 68,454. Pada tabel coeffecients diperoleh nilai $\mathrm{t}$ hitung $=$ 1,651 signifikan $(\alpha=0,05)$ untuk di uji dua pihak maka df atau dk (derajat kebebasan) $=$ jumlah responden -2 atau 60-2 $=58$, diperoleh $\mathrm{t}$ tabel $58=2,00$. Hasil perhitungan tersebut diatas menunjukan bahwa nilai $\mathrm{t}$ hitung $>\mathrm{t}$ tabel, atau 1,651>2,00 maka Ha di tolak dan Ho diterima, artinya tidak signifikan.Hasil korelasi dengan menggunakan persamaan pearson product moment variabel Gaya Gaya gaya kepemimpinan kepala sekolah dan kinerja guru diperoleh nilai koefesien r13 0,212 terhadap rtabel 0,080 yang dihitung terhadap (n) 60 responden pada taraf siginifikan $5 \%$.

Hasil ini menunjukan $\mathrm{r}$ hitung $>$ $r$ tabel yang bermakna terdapat hubungan yang kuat antara variabel gaya kepemimpinan kepala sekolah dengan kinerja guru.Kemudian diperoleh nilai $t$ hitung lebih besar daripada $\mathrm{t}$ tabel $(1,65<2,00)$ maka dapat disimpulkan bahwa koefesien 
korelasi variabel X2 dengan X1 dinyatakan tidak berarti atau koefesien korelasi tidak signifikan.Untuk membuktikan hipotesis tersebut "terdapat pengaruh langsung antara gaya kepemimpinan kepala sekolah dengan kepuasan kerja guru PAUD”, maka di uji menggunakan analisis jalur. Hasil perhitungan dengan menggunakan rumus matrik determinan p31 yang menunjukan hasil perolehan koefesien jalur sebesar 0,212.

Berdasarkan hipotesis pertama yang diajukan pada hipotesis statistik yaitu $\mathrm{H} 1$ diterima apabila p $31>0$ dan H0 diterima apabila p $31=0$, maka hasil tersebut menunjukan bahwa 0,212 >0 artinya dapat dijelaskan bahwa $\mathrm{H} 1$ diterima dan $\mathrm{H} 0$ ditolak. Kesimpulannya adalah terdapat pengaruh Gaya gaya kepemimpinan kepala sekolah (X1) terhadap Kepuasan kerja guru (X3).Kemudian untuk menguji keberartian hasil hipotesis atau signifikansinya berupa pengaruh langsung, hasil tersebut dibandingkan dengan probabilitas 0,05. Hasil menunjukan bahwa 0,129 >0,05 yang berarti signifikan atau terdapat pengaruh langsung gaya kepemimpinan kepala sekolah terhadap kinerja guru.

Besarnya konstribusi pengaruh yang diberikan diperoleh hasil sebesar $1,33 \%$, hal ini menunjukan pengertian bahwa kinerja guru dipengaruhi sebesar $1,33 \%$ oleh gaya kepemimpinan kepala sekolah, sedangkan sisanya (100\% $1,33 \%=98,67 \%$ ) dijelaskan sebabsebab yang lain. Koefesien jalur (p) berkisar angka 0 sampai 1, dengan catatan semakin kecil angka koefesien tersebut, semakin lemah pula pengaruh antar variabel.Jadi sudah sangat jelas terungkap bahwa gaya kepemimpinan kepala sekolah berpengaruh dalam meningkatkan kinerja guru di lingkup sekolahnya secara langsung.Gaya kepemimpinan yang berjalan dengan baik akan dapat mengarahkan guru untuk bekerja lebih baik dan dapat mengajak guru untuk bisa bekerja sama dan saling menghargai sehingga akan dapat menciptakan kenyamanan dalambekerja yang nantinya akan dapat enciptakan iklim organisasi sekolah yang kondusif. Iklim yang kondusif akan memberikan motivasi kepada guru dalam menjalankan tugas 
yang diberikan yang terlihat dari kinerja guru tersebut. Pendapat di atas diperkuat dengan Robin (2003:121) dan Rivai (2006:10) faktor yang mempengaruhi kinerja dibedakan atas faktor eksternal. 
Faktor internal meliputi dapat berupa disiplin, motivasi kerja, komitmen, sikap profesional, kecerdasan, pengetahuan dan kemampuan, mengendalikan diri. sedangkan faktor eksternal dapat berupa pelatihan, iklim organisasi, upah dan suasana kerja serta pelaksanaan pengawasan.

Pengaruh Iklim Organisasi Terhadap Kepuasan Kerja guru signifikansi $\quad 0,05$ diperoleh 7,08. Ternyata $F_{\text {hitung }}$ lebih kecil dari harga $\mathrm{F}_{\text {tabel }}\left(\mathrm{F}_{\text {hitung }}<\mathrm{F}_{\text {tabel }}\right)$, maka dapat disimpulkan bahwa bentuk regresi $\mathrm{X}_{3}$ atas $\mathrm{X}_{1}$ adalah tidak linear.

Hasil dari uji Coefficients dikemukakan nilai konstanta (a) = 116,59 dan beta $=0,218$. Dari tabel tersebut diperoleh persamaan linier perhitungannya adalah $: X_{3}=116,59+$ $\mathbf{0 , 2 1 8 X}_{2}$. Konstanta (a) 116,59 disimpulkan bahwa jika tidak ada iklim

Tabel 3. Anova

\begin{tabular}{|c|c|c|c|c|c|c|}
\hline \multirow[b]{2}{*}{ Model } & & \multicolumn{5}{|l|}{ Sum of } \\
\hline & & Squares & Df & Mean Square & $\mathrm{F}$ & Sig. \\
\hline \multirow[t]{3}{*}{1} & Regression & 455.119 & 1 & 455.119 & 2.805 & $.099^{\mathrm{a}}$ \\
\hline & Residual & 9411.065 & 58 & 162.260 & & \\
\hline & Total & 9866.183 & 59 & & & \\
\hline
\end{tabular}

Tabel 4. Coeffisien

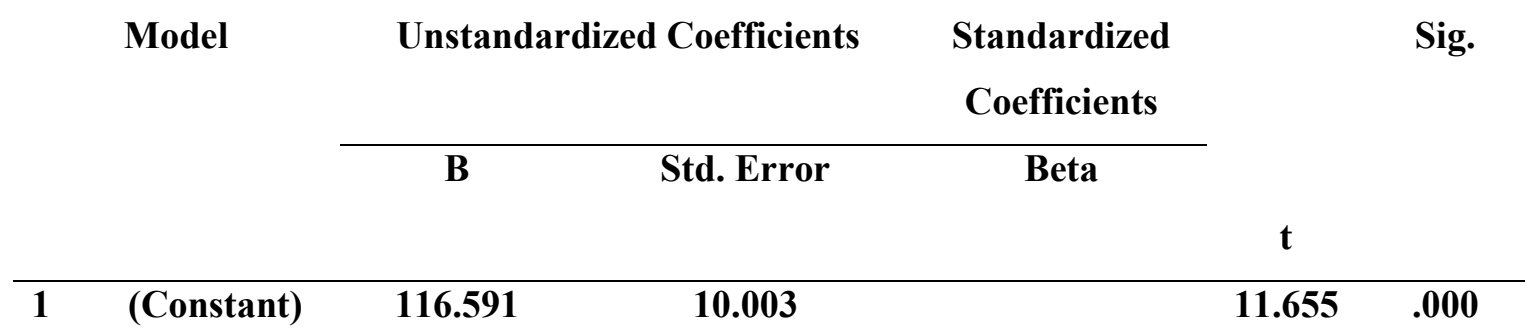

Tabel anova berikut menunjukan keberartian regresi melalui hasil yang diperoleh yaitu $F_{\text {hitung sebesar 2,805 }}$ dan harga $\mathrm{F}_{\text {tabel }}$ dengan $\mathrm{dk}$ pembilang 1 dan dk penyebut $(n-2=58)$ pada taraf organisasi, maka diperoleh nilai kinerja guru sebesar 116,59. Pada tabel coeffecients tersebut diperoleh $\mathrm{t}_{\text {hitung }}=$ 1,675 tingkat signifikan $(\alpha=0,05)$ di uji dua pihak maka df atau dk (derajat 
kebebasan) $=$ jumlah responden -2 atau $100-2=58$, diperoleh $\mathrm{t}_{\text {tabel }} 58=$ 2,00 . Hasil perhitungan tersebut diatas diperoleh bahwa nilai $t_{\text {hitung }}>t_{\text {tabel, }}$ atau 1,675 > 2,00 maka Ha di tolak dan Ho diterima, artinya tidak signifikan.

Hasil korelasi dengan menggunakan persamaan pearson product moment variabel Iklim organisasi dengan kinerja guru diperoleh nilai koefesien $\mathrm{r}_{23} 0,215$ terhadap $\mathrm{r}_{\text {tabel }(0,05)} 0,080$ yang dihitung terhadap (n) 60 responden pada taraf siginifikan $5 \%$. Hasil ini menunjukan $r$ hitung $>r_{\text {tabel }}$ artinya memiliki pengaruh yang kuat antara variabel iklim organisasi dengan kinerja guru.

Kemudian diperoleh nilai $t_{\text {hitung }}$ dari koefesien korelasi yang menunjukan bahwa lebih besar daripada $t$ tabel $(1,67<2,00)$ maka dapat disimpulkan bahwa koefesien korelasi variabel $\mathrm{X}_{2}$ dengan $\mathrm{X}_{3}$ dinyatakan tidak berarti atau koefesien korelasi tidak signifikan.Untuk membuktikan hipotesis "memiliki pengaruh langsung antara iklim organisasi dengan kinerja guru", maka di uji dengan menggunakan path analisys atau lebih dikenal dengan analisis jalur. Hasil perhitungan dengan menggunakan matrik determinan $\mathrm{p}_{32}$ menunjukan hasil perolehan koefesien jalur sebesar 0,215. Berdasarkan hipotesis kedua yang diajukan pada hipotesis statistik yaitu $\mathrm{H}_{0}$ diterima apabila $\mathrm{p}_{32}=0$ dan $\mathrm{H}_{2}$ diterima apabila $\mathrm{p}_{32}>0$, maka hasil tersebut menunjukan bahwa $0,215>0$ artinya dapat dijelaskan bahwa $\mathrm{H}_{1}$ diterima dan $\mathrm{H}_{0}$ ditolak. Kesimpulannya adalah terdapat pengaruhIklim organisasi terhadap kinerja.

Kemudian untuk menguji keberartian hasil hipotesis atau signifikansinya berupa pengaruh langsung, hasil tersebut dibandingkan dengan probabilitas 0,05 . Hasil menunjukan bahwa $0,137>0,05$ yang berarti signifikan atau terdapat pengaruh langsung iklim organisasi yang dimiliki oleh para guru terhadap kinerja guru.Besarnya konstribusi pengaruh yang diberikan diperoleh hasil sebesar $1,87 \%$, nilai tersebut menunjukan bahwa kinerja guru dipengaruhi $\quad 1,87 \quad \% \quad$ oleh iklim organisasi, sedangkan sisanya (100 \% $1,87 \%=98,13 \%)$ dijelaskan sebabsebab yang lain. Koefesien jalur 
berkisar angka 0 sampai 1, dengan catatan semakin kecil angka koefesien tersebut, semakin tidak kuat pula pengaruh antar variabel.

Walaupun konstribusi yang di pengaruhi sangat kecil, namun sudah sangat jelas terungkap dari hasil penelitian ini bahwa iklim organisasi berpengaruh

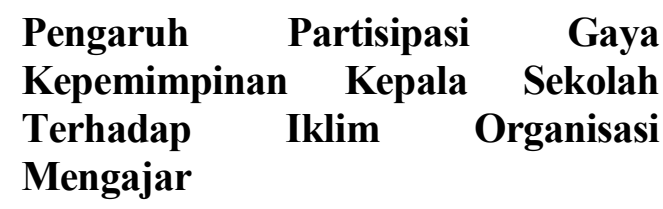

Konstanta (a) 20,323 menyatakan bahwa jika tidak ada gaya gaya kepemimpinan kepala sekolah, maka nilai iklim organisasi mengajar adalah 20,323.

Pada tabel coeffecients tersebut juga diperoleh $\mathrm{t}_{\text {hitung }}=5,877$ dengan tingkat signifikan $(\alpha=0,05)$ untuk di uji dua pihak maka df atau dk (derajat kebebasan) $=$ jumlah responden -2 atau $100-2=58$, diperoleh $t_{\text {tabel }} 98=$ 2,00. Hasil perhitungan tersebut

Tabel 5. Anova

\begin{tabular}{|c|c|c|c|c|c|c|}
\hline \multirow[b]{2}{*}{ Model } & & Sum of & & Mean & & \\
\hline & & Squares & Df & Square & $\mathrm{F}$ & Sig. \\
\hline \multirow[t]{3}{*}{1} & Regression & 2017.390 & 1 & 2017.390 & 34.540 & $.000^{\mathrm{a}}$ \\
\hline & Residual & 3387.593 & 58 & 58.407 & & \\
\hline & Total & 5404.983 & 59 & & & \\
\hline
\end{tabular}

Hasil dari uji Coefficients, diperoleh nilai konstanta $(\mathrm{a})=20,323$ dan beta $=$ 0,452 .

Dari tabel tersebut diperoleh persamaan linier adalah $: X_{2}=20,323+0,452 X_{I}$. diatas menunjukan bahwa nilai $\mathrm{t}_{\text {hitung }}>\mathrm{t}$ tabel, atau 5,877 > 2,00 maka Ho di tolak dan Ha diterima, artinya signifikan.

$\begin{array}{ccc}\text { Hasil } & \text { korelasi } & \text { dengan } \\ \text { menggunakan } & \text { persamaan } & \text { pearson }\end{array}$

Tabel 6. Coefficients

\begin{tabular}{|c|c|c|c|c|c|c|}
\hline & \multirow{3}{*}{ Model } & \multirow{2}{*}{\multicolumn{2}{|c|}{$\begin{array}{c}\text { Unstandardized } \\
\text { Coefficients }\end{array}$}} & \multirow{2}{*}{\multicolumn{3}{|c|}{$\begin{array}{l}\text { Standardized } \\
\text { Coefficients }\end{array}$}} \\
\hline & & & & & & \\
\hline & & $\bar{B}$ & Std. Error & Beta & $\mathrm{t}$ & Sig. \\
\hline \multirow[t]{2}{*}{1} & (Constant) & 20.323 & 10.290 & & 1.975 & .053 \\
\hline & Skor X1 & .452 & .077 & .611 & 5.877 & .000 \\
\hline
\end{tabular}


product moment variabel gaya kepemimpinan kepala sekolah dengan iklim organisasi mengajar diperoleh nilai koefesien $r_{12} 0,611$ terhadap $r_{\text {tabel }}$ 0,080 yang dihitung terhadap (n) 600 responden pada taraf siginifikan $5 \%$. Hasil ini menunjukan $r$ hitung $>r$ tabel yang bermakna terdapat hubungan antara variabel gaya kepemimpinan kepala sekolah dengan iklim organisasi.Kemudian diperoleh $\mathrm{t}_{\text {hitung }}=$ 5,87 dengan tingkat signifikan $(\alpha=$ $0,05)$ untuk di uji dua pihak maka df atau dk (derajat kebebasan) $=$ jumlah responden -2 atau $60-2=58$, diperoleh $\mathrm{t}_{\text {tabel }} 58=2,00$. Hasil perhitungan tersebut diatas menunjukan bahwa nilai $\mathrm{t}_{\text {hitung }}>\mathrm{t}$ tabel, atau 5,87 > 2,00 maka Ho di tolak dan Ha diterima, artinya koefesien korelasi signifikan.

Untuk membuktikan hipotesis “terdapat pengaruh langsung antara gaya gaya kepemimpinan kepala sekolah terhadap iklim organisasi mengajar", maka metode yang digunakan yaitu dengan menggunakan analisis jalur. Hasil perhitungan dengan menggunakan persamaan analisis jalur yaitu $\mathrm{r}_{12}=$ $\mathrm{p}_{21}$ yang menunjukan hasil perolehan

koefesien jalur sebesar 0,611. Hasil perhitungan tersebut terlampir pada Lampiran 6. Pengujian Hipotesis (B). Analisis Jalur Variabel $\mathrm{X}_{1}$ terhadap Variabel $\quad \mathrm{X}_{2} \quad\left(\mathrm{p}_{21}\right)$.Berdasarkan hipotesis ketiga yang diajukan pada hipotesis statistik yaitu $\mathrm{H}_{0}$ diterima apabila $\mathrm{p}_{21}=0$ dan $\mathrm{H}_{3}$ diterima apabila $\mathrm{p}_{21}>0$, maka hasil tersebut menunjukan bahwa $0,611>0$ artinya dapat dijelaskan bahwa $\mathrm{H}_{3}$ diterima dan $\mathrm{H}_{0}$ ditolak.

Tabel anova berikut menunjukan keberartian regresi melalui hasil yang diperoleh yaitu $F_{\text {hitung }}$ sebesar 34,540 dan nilai $F_{\text {tabel }}$ dengan $\mathrm{dk}$ pembilang 1 dan $\mathrm{dk}$ penyebut (n$2=58$ ) dengan signifikansi 0,05 diperoleh 7,08. Ternyata $F_{\text {hitung }}$ lebih besar dari harga $F_{\text {tabel }}\left(F_{\text {hitung }}>F_{\text {tabel }}\right)$, maka dapat disimpulkan bahwa bentuk regresi yaitu $X_{1}$ atas $X_{1}$ diperoleh linear dalam meningkatkan kinerja guru secara langsung.

$$
\text { Kesimpulannya adalah }
$$
terdapat pengaruh gaya kepemimpinan kepala sekolah terhadap iklim organisasi mengajar.Kemudian untuk menguji keberartian hasil hipotesis atau signifikansinya berupa pengaruh langsung, hasil tersebut 
dibandingkan dengan probabilitas 0,05. Hasil menunjukan bahwa 0,611>0,05 yang berarti signifikan atau terdapat pengaruh langsung gaya kepemimpinan kepala sekolah terhadap iklim organisasi.

Besarnya konstribusi pengaruh yang diberikan diperoleh hasil pengkuadratan koefesien jalur sebesar $37,33 \%$, hal ini menunjukan pengertian bahwa iklim organisasi mengajar $\left(\mathrm{X}_{2}\right)$ dipengaruhi sebesar $37,33 \%$ oleh gaya kepemimpinan kepala sekolah, sedangkan sisanya (100 $\%$ - 37,33 \% = 62,67 \%) yang dijelaskan oleh sebab-sebab yang lain. Koefesien jalur (p) berkisar angka 0 sampai 1, dengan catatan semakin kecil angka koefesien tersebut, semakin lemah pula pengaruh antar variabel.Jadi, dapat dijelaskan terungkap bahwa gaya kepemimpinan kepala sekolah berpengaruh dalam meningkatkan iklim organisasi secara langsung. Hasil penelitian ini sejalan dengan penelitian Miswan (2011: 15) yang menemukan adanya pengaruh yang tidak signifikan antara iklimorganisasi dengan kinerja dosen Pegawai Negeri Sipil pada Universitas Swasta di Kota Bandung.
Rangkuman hasil akhir dari pengujian hipotesis dan pembahasan hasil pengolahan data yang diperoleh pada penelitian ini dapat digambarkan semua pengaruh antar variabel yang saling berpengaruh secara langsung tersebut tersaji pada gambar sebagai berikut:

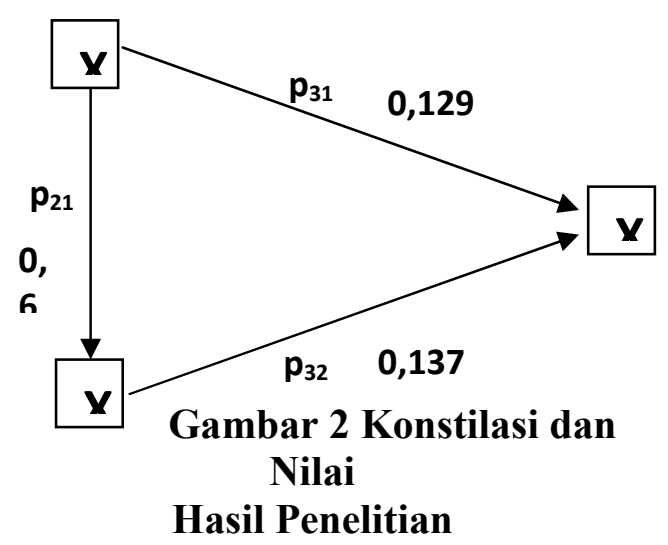

\section{Keterangan:}

X1 : Gaya kepemimpinan kepala sekolah

X2 : Iklim Organisasi

X3 : Kinerja guru PAUD (X3)

\section{PEMBAHASAAN}

Berdasarkan hasil peneltian di atas diperoleh konstribusi pengaruh yang diberikan diperoleh hasil sebesar $1,33 \%$, menunjukan tentang pengertian bahwa kinerja guru dipengaruhi sebesar 1,33\% oleh gaya gaya gaya kepemimpinan kepala sekolah,Jadi sudah sangat jelas 
terungkap bahwa gaya gaya gaya kepemimpinan kepala sekolah PAUD di Kabupaten mempawah berpengaruh dalam meningkatkan kepuasan kerja guru di lingkup sekolahnya secara langsung.

Besarnya konstribusi pengaruh yang diberikan diperoleh hasil sebesar $1,87 \%$, hal ini dapat dipahami bahwa kinerja guru dipengaruhi sebesar $1,87 \%$ oleh iklim organisasi. Walaupun konstribusi yang di pengaruhi sangat kecil, namun sudah sangat jelas terungkap dari hasil penelitian ini bahwa kinerja guru yang baik berpengaruh dalam mengkondisikan iklim organisasi secara langsung.

Besarnya konstribusi pengaruh yang diberikan diperoleh hasil pengkuadratan koefesien jalur sebesar $37,33 \%$, hal ini menunjukan pengertian bahwa iklim organisasi (X2) sebesar $37,33 \%$ oleh gaya kepemimpinan kepala sekolah. Selanjutnya dapat dijelaskan terungkap bahwa kepemimpinan kepala sekolah PAUD di Kabupaten Mempawah berpengaruh dalam meningkatkan kualitas iklim organisasi secara langsung
Berdasarkan perhitungan hasil penelitian menunjukan pengaruh antara gaya gaya gaya kepemimpinan kepala sekolah dan iklim sekolah terhadap kinerja guru PAUD hanya mencapai kategori sedang. Walaupun kategori sedang tetapi memiliki pengaruh secara langsung antara variable. Agar memiliki pengauh langsung dengan kategori tinggi kemampuan sebagai kepala sekolah dalam membimbing, mengerahkan dan mempengaruhi pola pikir guru agar dapat bersikap mandiri mempengaruhi, mendorong, menggerakkan guru, staff, siswa,orang tua siswa, serta pihak lain yang terkait untuk bekerja atau berperan serta guna mencapaitujuan yang telah ditetapkan

\section{KESIMPULAN}

Dari hasil pengujian hipotesis pertama tergambar jelas bahwa gaya kepemimpinan kepala sekolah saat ini masih lemah dan kurang dapat memberikan kontribusi bagi kepuasan kerja guru PAUD secara maksimal sehingga efektifitas dan tujuan dari proses pembelajaran yang dilaksanakan belum memuaskan. Namun sudah 
sangat jelas terungkap bahwa gaya gaya gaya kepemimpinan kepala sekolah berpengaruh secara langsung dalam meningkatkan kinerja guru.

Dari hasil pengujian hipotesis kedua tergambar jelas bahwa iklimorganisasi saat ini secara faktual masih lemah atau kurang dapat memberikan kontribusi bagi kinerja guru secara maksimal sehingga efektifitas dan tujuan dari prosespembelajaran yang dilaksanakan belum memuaskan. Namun sudah sangat jelas terungkap bahwa pofesionalisme guru mengajar berpengaruh secara langsung dalam meningkatkan kepuasan kerja guru.Dari hasil pengujian hipotesis ketiga tergambar jelas bahwa gaya gaya gaya kepemimpinan kepala sekolah yang dimiliki pada saat ini secara faktual cukup dapat memberikan kontribusi bagi iklimorganisasi secara maksimal sehingga pengembangan sekolah sudah dapat terlihat jelas. Jadi sudah sangat jelas terungkap bahwa gaya gaya kepemimpinan kepala sekolah berpengaruh secara langsung dalam membangun pofesionalisme guru mengajar.

\section{DAFTAR PUSTAKA}

Arif Jauhari. Kinerja Guru Berprestasi, Cetakan pertama, Penerbit: Badan. Penerbit FKM UI, Depok, 2005.

Edward Sallis. Total Quality Management in Education. Jogjakarta: IRCiSoD, 2006.

Heni Kusumawati. Kepemimpinaan Transformasional Sebagai Penggerak Perubahan Budaya Organisasi. Perspektif Jurnal Ekonomi Pembangunan, Manajemen dan Akuntansi. Vol 5 No 1, 2000.

Hersey, P. \& Blanchard, K.H. Management of organizational behavior (5 ${ }^{\text {th }} E d$.), pp. 169-201. Englewood Cliffs, NJ: Prentice Hall, 1988.

Hoy, W. K. \& Miskel, C. G. Educational administration: Theory, research, and practice, $9^{\text {th }}$ edition. New York: Mc. Graw-Hill, 2013.

Mangkunegara, A. A. Anwar Prabu, Manajemen Sumber daya Manusia Perusahaan, PT. : Bandung: Remaja Rosdakarya, 2004.

Miftah Thoha. Perilaku Organisasi (Konsep dasar dan perilakunya). Jakarta: Rajawali Press, 2009.

Mulysa. Manajemen dan gaya kepemimpinan kepala sekolah. Jakarta:PT.Bumi Aksara, 2012.

Rossow, W.B., A.D. Del Genio, and T. Eichler, Cloud-tracked winds from Pioneer Venus OCPP images. J. Atmos. Sci., 47, 2053-2084, doi:10.1175/15200469, 1990.

Suryaman. Budaya Organisasi di Sekolah: Jurnal Buana Pendidikan, Tahun 1, No. 1. 
Oktober 2004. ISSN 16938585., 2004.

Veithzal Rivai dan Deddy Mulyadi.

Kepemimpinan dan Perilaku Organisasi. Jakarta: Rajawali Pers, 2009.

Yuniarsih, Tjutju dan Suwatno. Manajemen Sumber Daya Manusia.Bandung: Alfa Beta, 2008. 